\title{
WATER QUALITY AND SEDIMENT RELATED TO THE OCCURRENCE OF AQUATIC MACROPHYTES IN LAGOA DA FRANCESA (PARINTINS -AM)
}

\author{
S. P. R. KIMURA ${ }^{1}$, D. PASCOALOTO ${ }^{2}$ and M. G. A. VEIRA ${ }^{1}$ \\ ${ }^{1}$ State University of Campinas, Department of Processes and Products Design \\ Email: melissagav@feq.unicamp.br \\ ${ }^{2}$ National Institute for Amazon Research, Coordination of Environmental Dynamics \\ solenisekimura@yahoo.com.br
}

\begin{abstract}
SUMMARY - The quality of water and sediment (organic matter) compartments of a pond and a lake located in the Amazon basin was analyzed, based on limnological variables such as nutrients (nitrogen and phosphorus), and dissolved oxygen, $\mathrm{pH}$, turbidity and suspended solids from water, and particle size distribution for the sediment. The occurrence of macrophytes was related to the quality of the compartments. Samples of water, sediment and macrophytes were collected in July and September 2012. The variables of water and sediment demonstrate their respective stages of preservation and pollution, in addition to demonstrating the anthropogenic influence on the quality of the compartments in the pond. The occurrence of aquatic macrophytes is associated to the provision of nutrients and can be used as a biological indicator of environmental quality. The sediment showed high contents of silt and clay, favorable to the accumulation of nutrients. Nitrogenous compounds (ammonia, nitrite and nitrate) indicated a recent pollution. Lower concentrations of dissolved oxygen (July 2012) are attributed to a high organic load carried by the excess of volume of rain during this period.
\end{abstract}

\section{INTRODUCTION}

Aquatic ecosystems have chemical and physical interactions between the organisms that are part of it Therefore, any imbalance in the midst affects the entire biota, causing temporary or permanent damages depending on the occurrence. The water bodies near the urban areas are the most affected, because usually receive a large load of domestic and industrial effluents.

According to Smith and Schindler (2009) the increase of nutrients in water bodies are assigned to launch of domestic and industrial effluents, or by runoff from agricultural areas which contributes to the increase of phosphated and nitrogenated substances, which are generally not found in high concentrations in not impacted aquatic environment. It is known that nitrogen $(\mathrm{N})$ and phosphorus $(\mathrm{P})$ are constituents of biomass of macrophytes and composes the molecules that act in metabolic processes. According to Van et al. (1999) the availability of these nutrients is one of the main factors that control the occurrence of aquatic macrophytes. However, according to Cavenaghi et al. (2003) these nutrients are the main elements involved in eutrophication of water bodies. 
Aquatic tropical environments, condition of the studied area, offer favorable climatic conditions to the growth of aquatic plants among them, the average high temperatures and intense solar radiation. Experimental studies by Pezzato (2007) and Cancian (2007) in different species of macrophytes indicate that species from tropical regions have better growth at high temperature. For Genevie et al. (1997) the temperature favors the primary production because it speeds up metabolic chemical reactions of macrophytes.

Under balanced conditions, the aquatic ecosystems have the self-purifying properties through physical, chemical and biological mechanisms. However, according to Cooney (1995), when the contaminants exceed the ability to purify these water bodies, the organisms present in the aquatic environment may suffer damage to its life cycle or even in its behavior, the result of these activities is a significant drop in the quality of water and loss of aquatic biodiversity, because of the disruption in the physical and chemical environment, and amendment of natural dynamics of the biological communities (Goulart and Callisto, 2003).

As regards the sediment, Esteves (2011) reports that it is the carrier that has the highest concentration of nutrients in aquatic ecosystem; thus, the study of this compartment has great importance for the understanding of the aquatic ecosystem. They subjected to interchange with the environment, and, according to the author, usually the highest rates of release of nutrients to the water column occur in anaerobic conditions (absence of oxygen), condition observed especially for phosphorus.

This study aimed to assess the quality of the water and sediment of the Lagoa da Francesa located in the municipality of Parintins/AM through the provision of nutrients in the compartments water and sediment and correlate this information with the occurrence of species of aquatic macrophytes identified at this site.

\section{MATERIAL AND METHODS}

\subsection{Area of study}

Two collections were carried out in the Lagoa da Francesa (Parintins-AM), one in July 2012, which corresponds to the high level of water, and the other in September 2012, period of low water level. Four points of collections were selected along the length of the lagoon with the objective of assessing the environmental quality as shown in Figure 1. The pond receives a large load of effluents from various activities installed around the lagoon. Figure 1 shows some of these sources of effluent discharge. The municipality of Parintins, site of the study area has no sewage treatment station, so the lagoon receives a large proportion of domestic sewage from homes and boats that have the location as a safe harbor. 


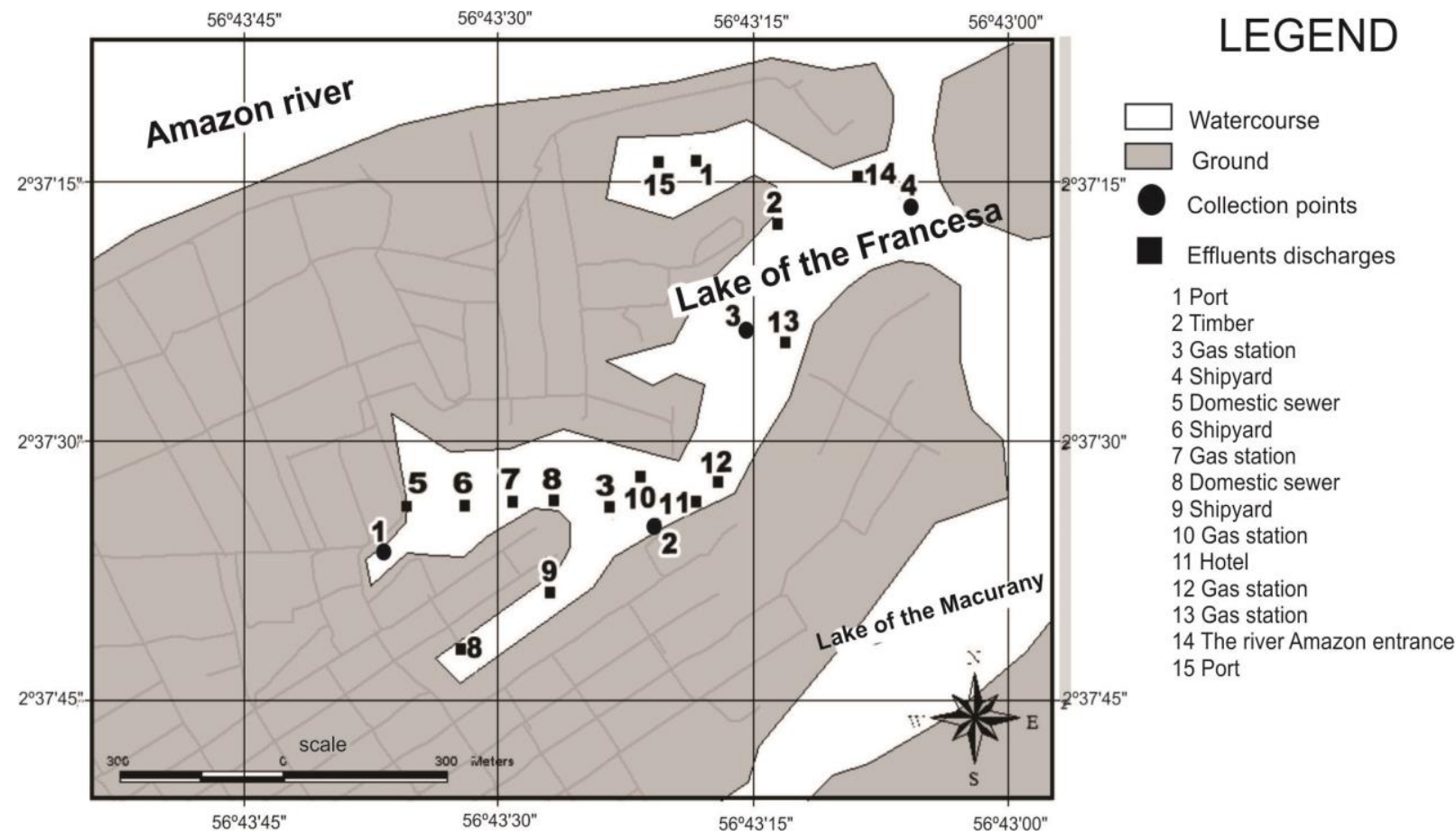

Figure 1 - Location of collection points of Lagoa da Francesa (Parintins - AM).

\subsection{Field Sampling and laboratory proceedings}

The samples of water were taken from the surface layer with a bottle type Van Dorn, stored in polyethylene bottles and sent to the Laboratory of Environmental Chemistry of INPA (Brazil-AM). The parameters $\mathrm{pH}$, dissolved oxygen and temperature were determined in the field using portable equipment, being for the $\mathrm{pH}$ using a $\mathrm{pH}$-meter model Quimis and conductivity a conductivity meter model Lutron CD-4303. Dissolved oxygen was determined by titrimetric method of Winkler APHA (2003). For turbidity it was used a turbidity meter, to determine the solids in suspension (APHA, 2003). Amomia, nitrite, nitrate and phosphate were determined by the FIA system (Flow Injection Analysis) according to the methodology described by Golterman (1970).

The sediment samples were collected at the same locations of water collection, using a device called Core. A surface composite sampling of $5 \mathrm{~cm}$ was used. The samples were identified and stored in plastic bags for later treatment at the Laboratory of Soil and Plants of INPA for determining particle size and chemistry described in Analyzes Manual - EMBRAPA (1999).

The species of macrophytes were collected from the observation and arrangement of banks. They were then collected and stored in plastic bags and sent to INPA for identification. Each sampling point was chosen considering the maximum number of species. However, many plants can exist only under certain conditions of hydrological and hydrochemicals regimes. 


\section{RESULTS AND DISCUSSION}

The temperature of the water in the Lagoa da Francesa ranged from 29.9 to $30.6{ }^{\circ} \mathrm{C}$ in July 2012 (rainy season) and from 32.4 to $34^{\circ} \mathrm{C}$ in September 2012 (less rainy). The average water temperature was compared with the average temperature of the air that are related with the precipitation in the region. We found that the variations in temperature of the water between the periods are in accordance with the specific conditions of the Amazon region.

The $\mathrm{pH}$ values indicate waters near the neutrality, with variations between the periods evaluated as shown in Figure 2 (a), higher values were obtained in September, the period of low water level and low rain, which ends up causing greater concentration of substances in the water.

The turbidity recorded low values in July 2012 with values ranging from 3.64 to 7.80 NTU and higher concentrations in September 2012, as shown in Figure 2 (b). We observed maximum values of 22.1 NTU for F2 and a minimum of $6.76 \mathrm{NTU}$ in point F1, mainly due to the dynamics of the hydrological regime of the region. The Lagoa da Francesa receives direct influence of the Amazon River and lakes located around the city. In the flood season (July) the waters of the lakes mingle with the waters of the Amazon River, these new features are observed in turbidity and suspended solids parameters, and visibly in the color of the water. In September, when the water level decreases, cease the connections with the lakes. Thus, the lagoa da Francesa has greater interference from the Amazon river, with high values for turbidity and suspended solids as shown in Figure 2 (b) and (c) and low values of transparencies determined with the Secchi disk, ranging from 25 to $30 \mathrm{~cm}$.
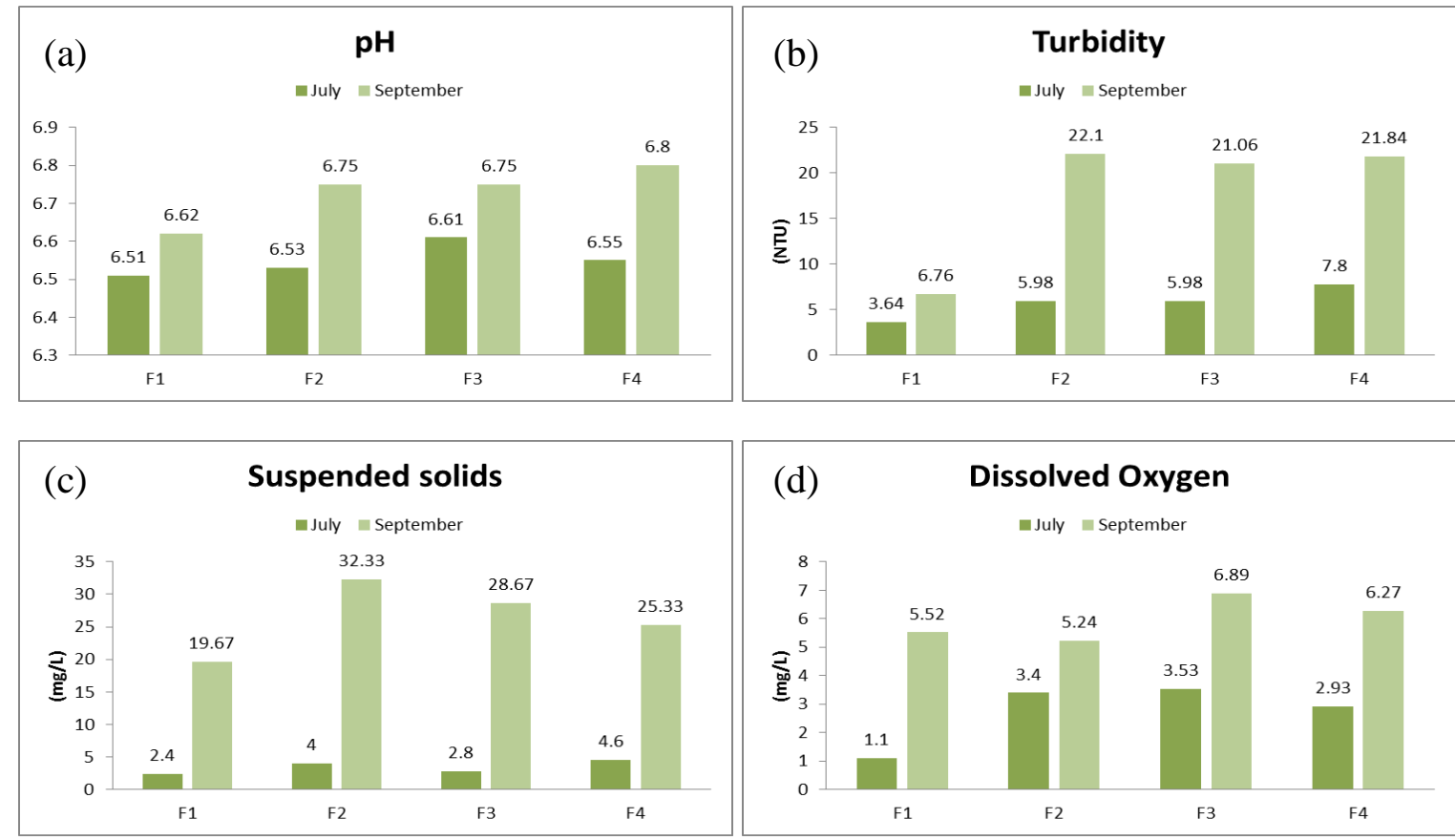

Figure 2 - Results of the parameters of water in the lagoa da Francesa (F1, F2, F3 and F4) in July and September 2012. 
The greatest concentrations of dissolved oxygen occurred in September with values ranging from 5.24 to $6.89 \mathrm{mg} \mathrm{L}^{-1}$, and low values in July 1.1 to $3.53 \mathrm{mg} \mathrm{L}^{-1}$, as shown in Figure 2 (d). Usually, these low values for July were not expected. However, considering that it is a rainy season and that there was no precipitation on the day before the collection, we impute such condition to increase of organic load that is carried by rain into the lagoon, contributing to the reduction of the oxygen consumed in the respiratory process of micro-organisms in the degradation of organic matter. It was also determined the concentration of phosphate in the water. However, it was not detected its presence, except in point $\mathrm{F} 1$ that achieved concentration of $0.031 \mathrm{mg} \mathrm{L}^{-1}$.

The particle size measurment presented a sediment with a higher percentage of clay and silt. At point F4 the percentage of sand was higher than the other points. According to Jones (2011), the clay has a great capacity for adsorption of phosphate, especially those formed by iron and aluminum ions. This adsorption capacity is maximized in an acid or slightly acid medium. The clay content of the sediment is a determining factor in adsorption and removal of phosphate of the water column.

Table 1 - Particle size distribution of the sediment of the lagoa da Francesa (F1, F2, F3 and F4) performed in July and September 2012.

\begin{tabular}{|c|c|c|c|c|}
\hline & & Sand $\%$ & Silt \% & Clay \% \\
\hline \multirow{2}{*}{ F1 } & July & 14.13 & 35.37 & 50.50 \\
\hline & September & 24.21 & 27.79 & 48.00 \\
\hline \multirow{2}{*}{ F2 } & July & 8.74 & 38.76 & 52.50 \\
\hline & September & 3.97 & 41.03 & 55.00 \\
\hline \multirow{2}{*}{ F3 } & July & 2.05 & 54.45 & 43.50 \\
\hline & September & 1.18 & 57.32 & 41.50 \\
\hline \multirow{2}{*}{ F4 } & July & 31.19 & 45.31 & 23.50 \\
\hline & September & 18.44 & 67.56 & 14.00 \\
\hline
\end{tabular}

The figures relating to the variation of nitrogen compounds are presented in Figure 3. Regarding to the process of decomposition of organic matter, the concentrations of ammonia, nitrite and nitrate can be used as an indicator of pollution. In F2, F3 and F4 the highest concentrations were obtained for nitrate, indicating an older pollution. The values ranged from 0.149 to $0.697 \mathrm{mg} \mathrm{L}^{-1}$ in July, and from 0.547 to $1.339 \mathrm{mg} \mathrm{L}^{-1}$ in September. The point $\mathrm{F} 1$ registered higher concentration for ammonia indicating recent pollution. This is the site of the lagoon that suffers greater anthropic intervention, demonstrating how the lagoon has been under changes lately. The availability of nitrate ion can justify the presence of aquatic macrophytes along the lagoon, once this ion is used in the development and growth of these plants. 


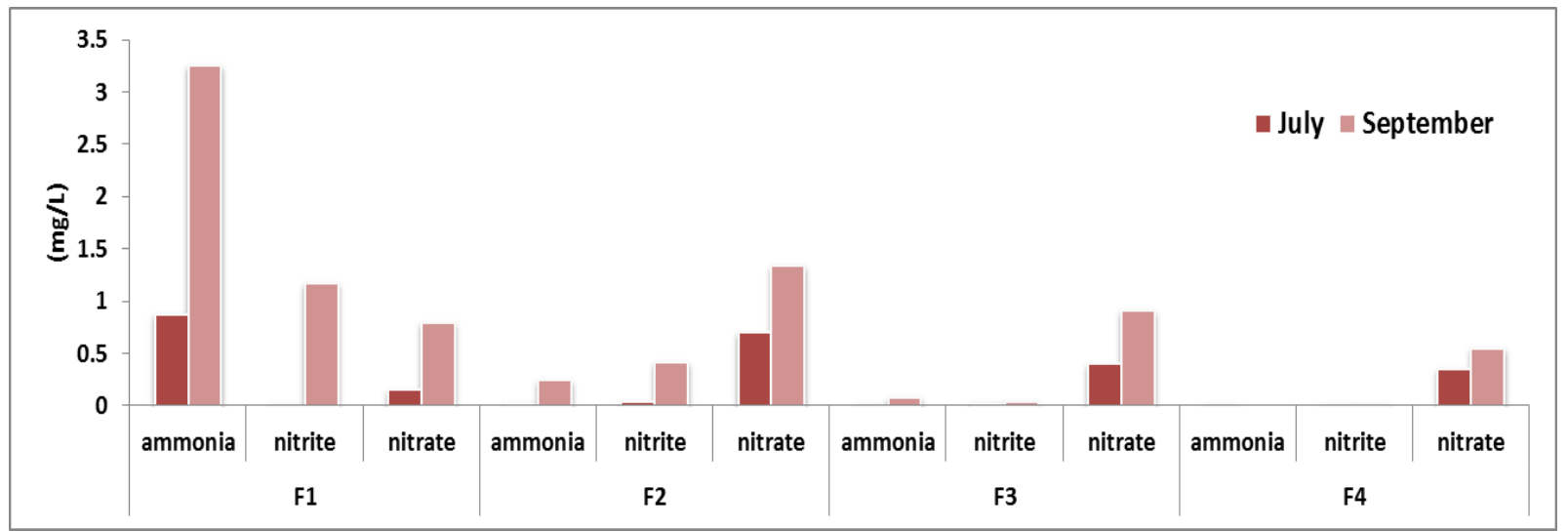

Figure 3 - Concentrations of nitrogenous compounds of water in lagoa da Francesa (F1, F2, F3 and F4) in July and September 2012.

As regards the composition of the sediment, this was characterized by the high content of organic matter, followed by phosphorus and nitrogen, as shown in Figure 4. According to Esteves (2011), the content of organic matter and nutrient is considerably greater in eutrophic lakes. According to the author, this sediment is easily recognized by its black color, due to the high concentration of organic matter. This was noticed in sediment samples collected in the lagoa da Francesa, with values ranging from 391.09 to $500.93 \mathrm{mg} \mathrm{kg}^{-1}$ in July, and 146.06 to $530.09 \mathrm{mg} \mathrm{kg}^{-1}$ in September.

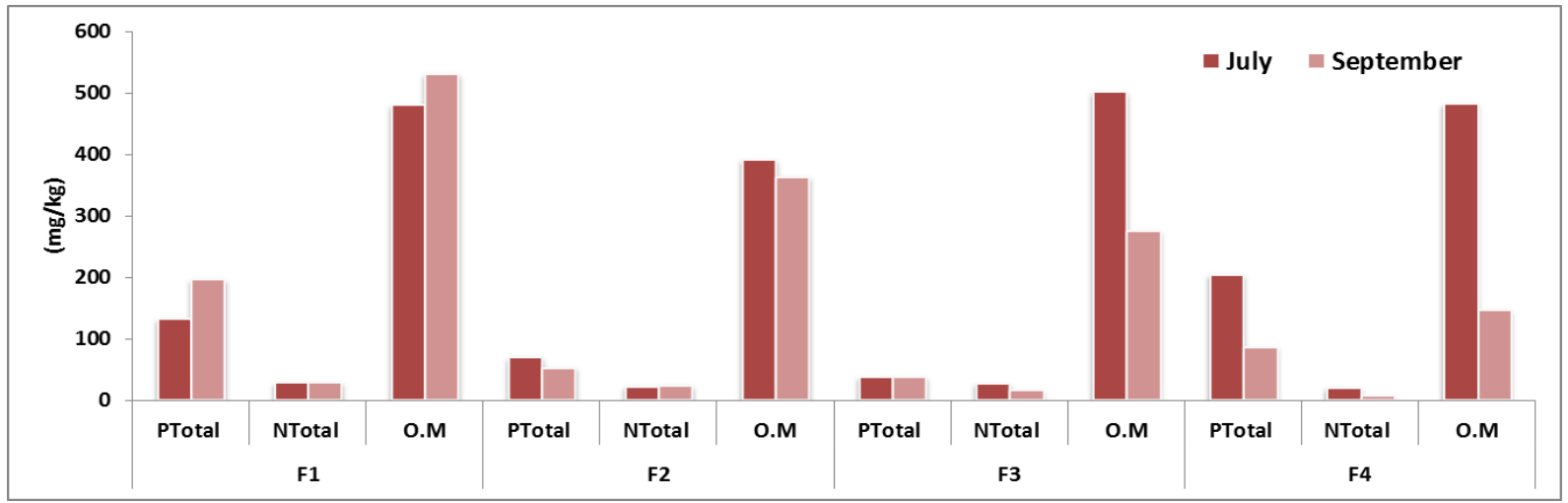

Figure 4 - Values of total $\mathrm{P}$, total $\mathrm{N}$ and organic matter in sediments of the Lagoa da Francesa (F1, F2, F3 and F4) in July and September 2012.

The sediment may constitute a more stable of nutrients and contribute to the growth of aquatic macrophytes. The aquatic plant species present in the lagoon are always the marginals and the floating. The arrangement of species at low depths according to Cavenaghi et al. (2003) allows even the root system of floating macrophytes use the stock of nutrients available in the sediment, justifying, 
partially, the occurrence of the species recorded in the lagoa da Francesa

\section{CONCLUSION}

The water from the lagoa da Francesa presents characteristics of Amazonian environments for some parameters such as $\mathrm{pH}$, temperature, turbidity, suspended solids and transparency and its behavior is in accordance with the hydrological regime of the region. The nitrogenous compounds and dissolved oxygen show how the lagoon has been impacted and, for both, public policies need to be taken to minimize this condition.

Similarly, the sediment with high levels of organic matter demonstrate the impact and has as aggravating factor its characteristic clay. Finally, we evidenced the presence of species of aquatic macrophytes in the pond that find favorable condition in the environment for their growth.

\section{ACKNOWLEDGMENTS}

The authors would like to thank FAPESP for the financial support and the INPA for the technical support.

\section{REFERENCES}

APHA, AWWA, WEF. Standard methods for the examination of water and wastewater. 21 ed., Washington, 2003.

CANCIAN, L. F. Crescimento das macrófitas flutuantes Pistia stratiotes s Salvinia molesta em diferentes condições de temperatura e fotoperíodo. Dissertação de mestrad.UNESP, Jaboticabal, Brasil. 55 p. 2007.

CAVENAGHI, A. L.; VELINI, E. D.; GALO, M. L. B. T.; CARVALHO, F. T.; NEGRISOLI, E.; TRINDADE, M. L. B.; SIMIONATO, J. L. A. Caracterização da qualidade de água e sedimento relacionados com a ocorrência de plantas aquáticas em cinco reservatórios da Bacia do rio Tietê. Planta Daninha, Virçosa-MG, 21, 43-52, 2003.

COONEY, J. D. Freshwater tests. In: Rand, GM (eds). Fundamentals of aquatic toxicology: effects, environmental fate, and risk assessment. Taylor \& Francis, Washington. p. 71-102, 1995.

ESTEVES, F. A. Fundamentos de Limonologia. $3^{\text {a }}$ ed. Rio de Janeiro: Intendência, 2011.

EMBRAPA, Manual de análises químicas de solos, plantas e fertilizantes. EMBRAPA, Brasília. 1999. 
GENEVIERE, M. C.; DUTHIE, H. C.; TAYLOR, W. D. Models de aquatic plants productivity: a review of the factors that influence growth. Aquatic Botany, 59, p. 195-215, 1997.

GOLTERMAN, H. L. Methods of chemical analysis of fresh water. Oxford: Blackwell Scientific Publications, 1970. 465p.

GOULART, M.; CALLISTO, M. Bioindicadores de qualidade de água como ferramenta em estudos de impacto ambiental. Revista FAPAM 2 (2), 153 - 164, 2003.

PEZZATO, M. M. Macrófitas aquáticas submersas: crescimento, fotossíntese e variáveis abióticas da água. Tese de doutorado. UFSCAR, São Carlos, Brasil. 95 p. 2007.

SMITH, V. H.; SCHINDLER, D. W. Eutrophication science: where do we go from here? Trends in Ecology and Evolution, vol. 24, no.4, p. 201-207, 2009.

VAN, T. K; WHEELER, G. S.; CENTER, T. D. Competicion between Hydrilla verticillata and Vallisneria americana as influenced by soil fertilility. Aquatic Botany, 62, p. 225-233, 1999. 